\title{
Study on the Clinico-Haematological Profile of Patients of Non-Transfusion Dependent Thalassemia (NTDT) Attending Thalassemia Clinic at a Tertiary Care Hospital
}

\author{
Indrani Das ${ }^{1}$, Ananya Sengupta룰 Abhishek Chakrabarti ${ }^{3}$, Arindam Kargupta ${ }^{4}$, Krishnendu Roy ${ }^{5}$
}

\begin{abstract}
${ }^{1}$ Department of General Medicine, Medical College and Hospital, Kolkata, West Bengal, India. ${ }^{2}$ Department of General Medicine, Medical College and Hospital, Kolkata, West Bengal, India. ${ }^{3}$ Department of General Medicine, Medical College and Hospital, Kolkata, West Bengal, India. ${ }^{4}$ Department of General Medicine, Medical College and Hospital, Kolkata, West Bengal, India. ${ }^{5}$ Department of General Medicine, Medical College and Hospital, Kolkata, West Bengal, India.
\end{abstract}

\section{ABSTRACT}

\section{BACKGROUND}

Non-Transfusion Dependent Thalassemia (NTDT) is a term used to label patients who do not require lifelong transfusions for survival. The common conditions traditionally described as NTDT are beta thalassemia intermedia, haemoglobin $\mathrm{H}$ disease and haemoglobin E beta thalassemia. The major problem with NTDT patients remains that, as they do not require regular transfusions, so they often do not seek medical attention until they develop serious complications such as anaemia due to ineffective erythropoiesis, iron overload, hypercoagulability and hormonal imbalances like hypogonadism, hypoparathyroidism, renal dysfunction etc.

\section{METHODS}

Our study was conducted in the Thalassemia Out Patient Department, Institute of Haematology \& Transfusion Medicine at Medical College, Kolkata, over a span of 1 year 6 months. It was a cross sectional observational study of 30 patients of NonTransfusion Dependant Thalassemia (NTDT) selected randomly as per the inclusion criteria. Thorough history taking and clinical examination were performed. Blood samples were tested for haemoglobin levels, RBC indices, fasting glucose, serum calcium, serum phosphate, SGPT, serum creatinine, TSH, FT4, FSH and LH (3 pooled samples at 30-minute-intervals), serum testosterone (in males) and serum ferritin. Ultrasonography and echocardiography were done. The data was analysed by standard statistical methods, using MedCalc (version 3.0) software. The correlation of different complications of NTDT with serum ferritin levels was done using MannWhitney $U$ test. An alpha level of $5 \%$ has been taken i.e. any p value $<0.05$ has been taken as significant.

\section{RESULTS}

Serum ferritin levels were found to be quite high in the NTDT patients, with a range of 335.1 (min.) - 1300 (max.) ng/mL, with a mean serum ferritin level of 568.78 $\mathrm{ng} / \mathrm{mL}$ and SD of 224.9 , despite the fact that nearly $87 \%$ (26 out of 30 ) of the patients had received less than 10 transfusions in their lifetime. Our study showed that, delayed puberty, renal dysfunction, liver dysfunction and pulmonary hypertension were found to be significantly related to the serum ferritin levels (serving as a marker of liver iron concentration).

\section{CONCLUSIONS}

Thus, we conclude that despite requiring much fewer transfusions than transfusion dependant thalassemia patients, the NTDT patients do develop iron overload as well as different complications, some of which are significantly related to the liver iron overload. Knowledge of such complications could help to initiate chelation therapy at the appropriate time for NTDT patients, thereby reducing morbidity and improving their quality of life.

\section{KEY WORDS}

Non-Transfusion Dependent Thalassemia (NTDT), Ferritin

\author{
Corresponding Author: \\ Indrani Das, \\ Flat No. 0/4, Cluster 8, \\ Purbachal Housing, Salt Lake, \\ Sector 3, Kolkata-700097, \\ West Bengal, India. \\ E-mail: dr_indranidas@rediffmail.com
}

DOI: $10.14260 /$ jemds/2020/322

Financial or Other Competing Interests: None.

How to Cite This Article:

Das I, Sengupta A, Chakrabarti A, et al. Study on the clinico-haematological profile of patients of non-transfusion dependent thalassemia (NTDT) attending thalassemia clinic at a tertiary care hospital. J. Evolution Med. Dent. Sci. 2020;9(18): 1475-1479, DOI: 10.14260/jemds/2020/322

Submission 17-02-2020,

Peer Review 17-04-2020,

Acceptance 23-04-2020,

Published 04-05-2020. 


\section{BACKGROUND}

Thalassemias are a group of inherited haemoglobin disorders characterized by the defective synthesis of the alpha- or betachains of adult haemoglobin A. Transfusion dependence, from the patient's as well as the clinician's point of view, is a very important issue. However, at the other end of the spectrum lie the non-transfusion dependent thalassemias (NTDT). NTDT is a term used to label patients who do not require lifelong transfusions for survival, although they may require occasional or even frequent transfusions in certain clinical settings and for certain defined periods of time. ${ }^{[1]}$ Hence, we surmised that a study of the most common complications and their co relation to the body's iron load as measured by serum ferritin, would help in future, to identify those at risk at an earlier stage. The common conditions traditionally described as NTDT are[2]

- Beta thalassemia intermedia.

- Haemoglobin E beta thalassemia.

- Haemoglobin H disease.

As per the 2011 Census, India has a prevalence of beta thalassemia carriers is around $1-17 \%$ and that of $\mathrm{Hb} \mathrm{E}$ carriers around $2-50 \% .{ }^{[3]}$ Regardless of specific subtype, all NTDT patients are prone to develop certain morbidities, which can be attributed to chiefly the following pathophysiologic processes: ${ }^{[4]}$

Transfusion independence does not mean freedom from complications in NTDT patients. NTDT patients also suffer from anaemia, although usually less severe than transfusion dependant thalassemia patients. As a consequence of chronic anaemia and ineffective erythropoiesis, there occurs growth retardation, facial dysmorphism and extramedullary haematopoiesis. Secondly, ineffective erythropoiesis results in increased gastrointestinal iron absorption. [5] Such iron overload, which may be reflected in the serum ferritin levels, can in turn, lead to hepatic or cardiac fibrosis, with increased risk of hepatocellular carcinoma or cardiac dysfunction. Iron loads are best reflected by MRI based liver iron assessment. ${ }^{[6]}$ Thirdly, factors such as abnormal circulating RBCs \& platelets may lead to hypercoagulable states, resulting in thrombotic episodes, chronic leg ulcers and pulmonary hypertension with secondary right ventricular dysfunction. ${ }^{[7]}$

In addition, NTDT patients may also develop many other complications such as hormonal deficiencies eg. hypothyroidism, hypoparathyroidism, diabetes mellitus or hypogonadism (mainly due to ineffective erythropoiesis, medullary expansion \& iron mediated target gland damage), osteoporosis and renal dysfunction. The major problem with NTDT patients remains that, as they do not require regular transfusions, they often do not seek medical attention until they develop serious complications. Hence, we surmised that a study of the most common complications and their co relation to the body's iron load would help in future to identify those at risk at an earlier stage, thereby improving the quality of life of NTDT patients with appropriate preventive or remedial measures. A recent longitudinal follow-up over a 10-year period confirmed these findings, and a serum ferritin level of $\geq 800 \mathrm{ng} / \mathrm{mL}$ was the threshold after which all patients became at risk of developing morbidity.[8]

\section{Objectives}

1. To assess the complications of NTDT patients.

2. To co relate the complications with their genotypes.

3. To correlate the iron load (serum ferritin level) with the complications present. which would enable us to predict or recognize such problems early.

\section{METHODS}

This cross-sectional observational study was done in Thalassemia OPD, Institute of Haematology and Transfusion Medicine (IHTM), Medical College Hospital from Jan 2014 to July 2015 among thirty non-transfusion dependant thalassemia (NTDT) patients of both genders attending Thalassemia OPD through purposive sampling.

\section{Total Study Population}

Out of the total 42 patients assessed, 12 were excluded based on presence of different exclusion criteria. Rest 30 patients of NTDT, satisfying the inclusion criteria were analysed.

\section{Parameters to Be Studied}

- History taking.

- Clinical examination.

- Laboratory investigations.

- Radiological investigations.

- Study of medical records.

\section{Study Tools}

A. History taking \& Examination of Medical Records

- Number of transfusions in past.

- Presence of symptomatic anaemia (easy fatiguability, generalized weakness, palpitations)

- $\quad$ Past history of non-healing leg ulcers.

- Past history of gallstones.

- $\quad$ Age of onset of puberty.

B. Clinical examination:

- Facial dysmorphism.

- Presence of hepatosplenomegaly

- Presence of leg ulcers.

- Measurement of height \& weight.

- Sexual Maturity Rating.

C. Blood Examination:

- Hb levels, RBC indices.

- Blood for fasting glucose, serum calcium, serum phosphate, SGPT, serum creatinine.

- Blood levels of TSH, FT4, FSH, LH, serum testosterone (in males).

- $\quad$ Serum ferritin levels.

D. Radiological Evaluation:

- USG abdomen for endometrial thickness (in females) and presence of gall stones \& hepatosplenomegaly. 
- Echocardiography for presence of pulmonary hypertension by TRV measurement.

\section{Inclusion Criteria}

- $\quad$ Age $>2$ yrs. at diagnosis.

- $\mathrm{Hb}$ values between $7 \mathrm{gm} / \mathrm{dL}$ and $9 \mathrm{gm} / \mathrm{dL}$ without the need for regular transfusion regimen (at diagnosis) in patients with or without splenomegaly.

- No transfusion within previous 6 months prior to study entry.

- $\quad$ Serum ferritin $>300 \mathrm{ng} / \mathrm{mL}$.

\section{Exclusion Criteria}

1. HbS variants of thalassemia syndrome.

2. Anticipated regular transfusion during study.

3. Age $<2$ yrs. at diagnosis.

4. Lab values: $\mathrm{Cr} \mathrm{Cl}</=40 \mathrm{~mL} / \mathrm{sqm} \mathrm{BSA} / \mathrm{min}$, serum creatinine levels $>$ upper limit of normal, SGPT $>5$ times upper limit of normal.

\section{Study Technique}

Meeting the inclusion and exclusion criteria, 30 patients of Non-transfusion dependant thalassemia were selected. Thorough history taking and clinical examination were performed, and previous medical records examined.

Blood samples were drawn and tested for various parameters, viz. haemoglobin levels, RBC indices, fasting glucose, serum calcium, serum phosphate, SGPT, serum creatinine, TSH, FT4, FSH and LH (3 pooled samples at 30 minutes interval), serum testosterone (in males) and serum ferritin. All the investigations were done in the hospital itself.

Patients also had an ultrasonography of abdomen done to determine liver and spleen size, presence of gallstones and endometrial thickness (in females). Echocardiography was done to determine presence of pulmonary hypertension by estimation of TRV. All radiological investigations were done by the same operator for all patients in order to minimize variability in interpretation.

The results were interpreted according to thresholds well accepted for clinical use and predefined on the basis of published literature.

\section{Statistical Methods}

The data was analysed by standard statistical methods, using MedCalc (version 3.0) software. The categorical variables were expressed as number of patients and percentage of patients and compared across the groups using Pearson's Chi Square test for Independence of Attributes. Continuous variables were expressed as Mean +/- Standard deviation. Pvalue was calculated using the Chi- square test for testing the significance of the tests. A p- value of $<0.05$ was considered" significant" and $>0.05$ as "not significant" The co relation of different complications of NTDT with serum ferritin levels was calculated using Mann-Whitney $U$ test. The statistical software MedCalc version 3.0 has been used for the analysis. An alpha level of $5 \%$ has been taken i.e. any $p$ value $<0.05$ has been taken as significant.

\section{Ethical Considerations}

An informed consent was obtained from each participant prior to their enrolment in the study. The study was approved by Ethics Committee.

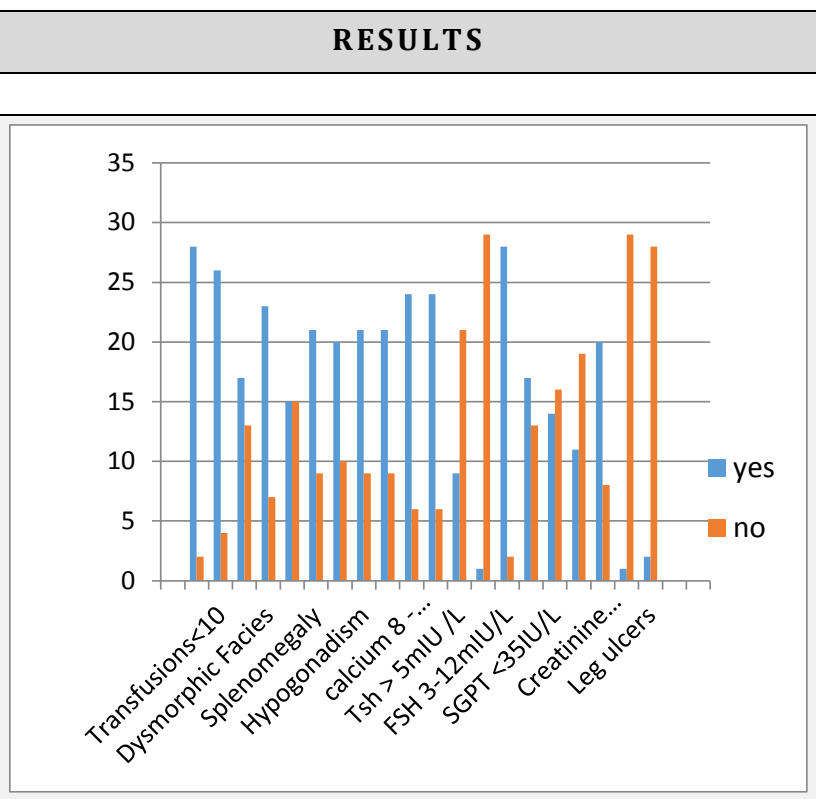

Descriptive Statistics of Various Parameters Studied in NTDT Patients

\begin{tabular}{|c|c|c|c|c|c|}
\hline \multicolumn{6}{|c|}{ Gender } \\
\hline Gender & $\begin{array}{l}\text { Total No. of } \\
\text { Subjects }\end{array}$ & $\begin{array}{l}\text { Mean Serum } \\
\text { Ferritin }\end{array}$ & SD & $\begin{array}{c}\mathbf{p} \\
\text { Value }\end{array}$ & Significance \\
\hline Male & 16 & 507.5 & 272.72 & & \\
\hline Female & 14 & 524.8 & 158.97 & 0.9 & Not significant \\
\hline Total & 30 & & & & \\
\hline Age & $\begin{array}{l}\text { Total No. of } \\
\text { Subjects }\end{array}$ & $\begin{array}{c}\text { Age } \\
\text { Mean Serum } \\
\text { Ferritin }\end{array}$ & SD & $\begin{array}{c}\mathbf{p} \\
\text { Value }\end{array}$ & Significance \\
\hline$</=18$ yrs. & 11 & 393.0 & 83.67 & & \\
\hline$>18$ yrs. & 19 & 559.3 & 241.18 & 0.001 & Significant \\
\hline Total & 30 & & & & \\
\hline \multicolumn{6}{|c|}{ Number of transfusions } \\
\hline $\begin{array}{c}\text { No of } \\
\text { transfusions }\end{array}$ & $\begin{array}{l}\text { Total No. of } \\
\text { Subjects }\end{array}$ & $\begin{array}{l}\text { Mean Serum } \\
\text { Ferritin }\end{array}$ & SD & $\begin{array}{c}\mathbf{p} \\
\text { Value }\end{array}$ & Significance \\
\hline$<10$ & 26 & 507.05 & 141.08 & & \\
\hline$>10$ & 4 & 946.0 & 273.36 & 0.004 & Significant \\
\hline Total & 30 & & & & \\
\hline \multicolumn{6}{|c|}{ Symptomatic anaemia } \\
\hline $\begin{array}{c}\text { Symptomatic } \\
\text { anaemia }\end{array}$ & $\begin{array}{l}\text { Total No. of } \\
\text { Subjects }\end{array}$ & $\begin{array}{l}\text { Mean Serum } \\
\text { Ferritin }\end{array}$ & SD & $\begin{array}{c}\mathbf{p} \\
\text { Value }\end{array}$ & Significance \\
\hline Present & 17 & 546.1 & 263.19 & & \\
\hline Absent & 13 & 430.2 & 108.56 & 0.07 & Not Significant \\
\hline Total & 30 & & & & \\
\hline \multicolumn{6}{|c|}{ Facial dysmorphism } \\
\hline $\begin{array}{c}\text { Facial } \\
\text { dysmorphism }\end{array}$ & $\begin{array}{l}\text { Total No. of } \\
\text { Subjects }\end{array}$ & $\begin{array}{l}\text { Mean Serum } \\
\text { Ferritin }\end{array}$ & SD & $\begin{array}{c}P \\
\text { Value }\end{array}$ & Significance \\
\hline Present & 23 & 524.1 & 232.02 & & \\
\hline Absent & 7 & 427.0 & 203.8 & 0.339 & Not Significant \\
\hline Total & 30 & & & & \\
\hline \multicolumn{6}{|c|}{ Different Parameters with Serum Ferritin Levels } \\
\hline
\end{tabular}

\section{Descriptive Statistics of Various Parameters Studied in NTDT Patients}

Of the 30 patients studied, $16(53 \%)$ were male and $14(47 \%)$ female, with Male: Female ratio of 1.14:1. Of the 11 patients of age $<18$ yrs. studied, $5(45 \%)$ had height above the $3^{\text {rd }}$ centile, while $6(55 \%)$ had height below $3^{\text {rd }}$ centile. Of the 14 female patients studied, $10(71 \%)$ had normal endometrial thickness for age while 4 (29\%) had low endometrial thickness. All the 16 male patients $(100 \%)$ were found to 
have normal serum testosterone levels. Of the 14 female patients studied, 10 (71\%) had normal endometrial thickness for age while 4 (29\%) had low endometrial thickness. Several other parameters were studied in the 30 patients as shown in the multiple bar diagram below.

\begin{tabular}{|c|c|c|c|c|c|}
\hline \multicolumn{6}{|c|}{ Hepatomegaly } \\
\hline Hepatomegaly & $\begin{array}{l}\text { Total No. of } \\
\text { Subjects }\end{array}$ & $\begin{array}{c}\text { Mean Serum } \\
\text { Ferritin }\end{array}$ & SD & $P$ Value & Significance \\
\hline Present & 15 & 546.1 & 268.27 & \multirow{2}{*}{0.187} & \multirow{2}{*}{ Not Significant } \\
\hline Absent & 15 & 430.2 & 160.31 & & \\
\hline Total & 30 & & & & \\
\hline \multicolumn{6}{|c|}{ Splenomegaly } \\
\hline Splenomegaly & $\begin{array}{l}\text { Total No. of } \\
\text { Subjects }\end{array}$ & $\begin{array}{c}\text { Mean Serum } \\
\text { Ferritin }\end{array}$ & SD & $P$ Value & Significance \\
\hline Present & 21 & 536.5 & 189.13 & \multirow{2}{*}{0.129} & \multirow{2}{*}{ Not Significant } \\
\hline Absent & 9 & 424.1 & 305.2 & & \\
\hline Total & 30 & & & & \\
\hline \multicolumn{6}{|c|}{ BMI } \\
\hline BMI & $\begin{array}{l}\text { Total No. of } \\
\text { Subjects }\end{array}$ & $\begin{array}{l}\text { Mean Serum } \\
\text { Ferritin }\end{array}$ & SD & P Value & Significance \\
\hline$>18.5$ & 20 & 530.3 & 195.18 & \multirow{3}{*}{0.914} & \multirow[b]{2}{*}{ Not Significant } \\
\hline$<18.5$ & 10 & 510.6 & 286.94 & & \\
\hline Total & 30 & & & & \\
\hline SMR & $\begin{array}{l}\text { Total No. of } \\
\text { Subjects }\end{array}$ & $\begin{array}{c}\text { SMR } \\
\text { Mean Serum } \\
\text { Ferritin }\end{array}$ & SD & P Value & Significance \\
\hline Apt for age & 8 & 386.6 & 123.08 & \multirow{3}{*}{0.002} & \multirow{3}{*}{ Significant } \\
\hline Not apt for age & 22 & 541.3 & 237.73 & & \\
\hline Total & 30 & & & & \\
\hline \multicolumn{6}{|c|}{ Haemoglobin levels } \\
\hline Hb & $\begin{array}{l}\text { Total No. of } \\
\text { Subjects }\end{array}$ & $\begin{array}{l}\text { Mean serum } \\
\text { ferritin }\end{array}$ & SD & P Value & Significance \\
\hline$>7 \mathrm{gm} / \mathrm{dL}$ & 21 & 509.0 & 199.77 & \multirow{3}{*}{0.354} & \multirow{3}{*}{ Not Significant } \\
\hline$<7 \mathrm{gm} / \mathrm{dL}$ & 9 & 546.1 & 281.62 & & \\
\hline Total & 30 & & & & \\
\hline
\end{tabular}

\begin{tabular}{|c|c|c|c|c|c|}
\hline \multicolumn{6}{|c|}{ Serum Calcium } \\
\hline Calcium & $\begin{array}{l}\text { Total No .of } \\
\text { Subjects }\end{array}$ & $\begin{array}{l}\text { Mean Serum } \\
\text { Ferritin }\end{array}$ & SD & P Value & Significance \\
\hline Normal & 24 & 531.0 & 184.26 & & \\
\hline Abnormal & 6 & 403.6 & 369.52 & 0.147 & Not Significant \\
\hline Total & 30 & & & & \\
\hline \multicolumn{6}{|c|}{ Serum Phosphate } \\
\hline Phosphate & $\begin{array}{l}\text { Total No. of } \\
\text { Subjects }\end{array}$ & $\begin{array}{l}\text { Mean Serum } \\
\text { Ferritin }\end{array}$ & SD & P Value & Significance \\
\hline Normal & 24 & 531.0 & 184.26 & & \\
\hline Abnormal & 6 & 403.6 & 150.85 & 0.147 & Not Significant \\
\hline Total & 30 & & & & \\
\hline \multicolumn{6}{|c|}{ Serum TSH } \\
\hline TSH & $\begin{array}{l}\text { Total No. of } \\
\text { Subjects }\end{array}$ & $\begin{array}{c}\text { Mean Serum } \\
\text { Ferritin }\end{array}$ & SD & P Value & Significance \\
\hline Normal & 21 & 505.1 & 237.78 & & \\
\hline Abnormal & 9 & 524.1 & 203.8 & 0.402 & Not Significant \\
\hline Total & 30 & & & & \\
\hline \multicolumn{6}{|c|}{ Serum FSH Levels } \\
\hline TSH & $\begin{array}{l}\text { Total No. of } \\
\text { Subjects }\end{array}$ & $\begin{array}{l}\text { Mean Serum } \\
\text { Ferritin }\end{array}$ & SD & P Value & Significance \\
\hline Normal & 28 & 510.65 & 222.05 & 0.212 & Not Significant \\
\hline Abnormal & 2 & 733.5 & 278.6 & & \\
\hline Total & 30 & & & & \\
\hline \multicolumn{6}{|c|}{ Serum SGPT Levels } \\
\hline SGPT & $\begin{array}{l}\text { Total No. of } \\
\text { Subjects }\end{array}$ & $\begin{array}{l}\text { Mean Serum } \\
\text { Ferritin }\end{array}$ & SD & P Value & Significance \\
\hline$<35 \mathrm{IU} / \mathrm{L}$ & 14 & 425.6 & 128.63 & & \\
\hline$>35 \mathrm{IU} / \mathrm{L}$ & 16 & 542.4 & 263.76 & 0.04 & Significant \\
\hline Total & 30 & & & & \\
\hline \multicolumn{6}{|c|}{ Different Parameters with Serum Ferritin Levels } \\
\hline
\end{tabular}

\section{DISCUSSION}

Our study was conducted in the Thalassemia Outpatient Department, Institute of Haematology \& Transfusion Medicine at Medical College, Kolkata over a span of 1 year 6 months. It was a cross sectional observational study. Overall
30 patients of Non-Transfusion Dependant Thalassemia (NTDT) who attended the Thalassemia OPD during this period and fitted into our inclusion criteria, were studied. In our study, we tried to determine the prevalence of different complications in NTDT patients and to co relate these complications with the serum ferritin level, which is a cheap and convenient way to estimate iron load in resource poor settings.

In our study, age of patients ranged from 6 yrs. to 50 yrs., of whom 16 were male and 14 were female. The mean serum ferritin level in males was $594.6 \mathrm{ng} / \mathrm{mL}$, with a SD of 272.7; while the mean serum ferritin level in females was 539.2 $\mathrm{ng} / \mathrm{mL}$, with a SD of 158.9. There was no significant difference in serum ferritin levels between the sexes. ( $p$ value $=0.9$ ). Mean serum ferritin levels were found to increase significantly with age. [mean SF in those $<=20$ yrs of age $181.74 \mathrm{ng} / \mathrm{mL}$, SD 159.58; mean SF in those $>20$ yrs of age $368.25 \mathrm{ng} / \mathrm{mL}$, SD 261.96; $\mathrm{p}$ value $=0.007$ ]. Of the total 30 patients studied, 28 were $\mathrm{E}$ beta thalassemia and 2 were beta intermedia thalassemia. The $\mathrm{E}$ beta thalassemia population had a mean $\mathrm{SF}$ of $577.73 \mathrm{ng} / \mathrm{mL}, \mathrm{SD} 229.71$. The beta intermedia thalassemia group had a mean SF of $443.4 \mathrm{ng} / \mathrm{mL}$, SD 92.77. Our study showed that, among the various complications studied, the following parameters were found to be significantly related to the serum ferritin levels (serving as a marker of LIC) delayed puberty as determined on the basis of history, physical examination and $\mathrm{ng} / \mathrm{mL}$, SD 123.3; mean SF level of those with delayed puberty $624.26 \mathrm{ng} / \mathrm{mL}$, SD 237.73; $\mathrm{p}$ value $=0.01$ ] liver dysfunction (as determined by serum medical records) [mean SF level of those with timely onset of puberty was 439.3. SGPT levels $>35 \mathrm{IU} / \mathrm{mL}$ ] [mean SF of those with normal liver function $479.68 \mathrm{ng} / \mathrm{mL}$, SD 124.63; SF of those with SGPT >35 IU $/ \mathrm{mL} 646.73 \mathrm{ng} / \mathrm{mL}$, SD 263.76; $\mathrm{p}$ value $=0.04]$. Renal dysfunction: Mean SF of those with creatinine clearance greater than $90 \mathrm{ml} / \mathrm{sqm} / \mathrm{min}$ was $465.65 \mathrm{ng} / \mathrm{mL}$, SD 24.11; mean SF of those with creatinine clearance $60-89 \mathrm{ml} / \mathrm{sqm} / \mathrm{min}$ was $569.2 \mathrm{ng} / \mathrm{mL}$, SD 186.29; $p$ value $=0.043$

However, the difference in serum ferritin levels between those with creatinine clearance greater than $90 \mathrm{ml} / \mathrm{sqm} / \mathrm{min}$ and those with values less than $60 \mathrm{ml} / \mathrm{sqm} / \mathrm{min}$ was found to be not significant ( $p$ value $=0.485$ ); possibly because the number of subjects in the latter group was too small. Pulmonary hypertension (as determined by echocardiography with TRV $>2.5 \mathrm{~m} / \mathrm{sec}$ ). [Mean SF of those with TRV $<2.5 \mathrm{~m} / \mathrm{sec} 458.89 \mathrm{ng} / \mathrm{mL}$, SD 76.71; mean SF of those with TRV $<2.5 \mathrm{~m} / \mathrm{sec} 758.58 \mathrm{ng} / \mathrm{mL}$, SD 271.18; p value $=0.001]$

Serum ferritin levels were found to be quite high in the NTDT patients, with a range of 335.1 (min.) -1300 (max.) $\mathrm{ng} / \mathrm{mL}$, with a mean serum ferritin level of $568.78 \mathrm{ng} / \mathrm{mL}$ and SD of 224.9; despite the fact that nearly $87 \%$ (26 out of 30 ) of the patients had received less than 10 transfusions in their lifetime. Although NTDT patients accumulate iron at lower rates than those receiving regular transfusions, a significant number of them do develop a clinically significant liver iron concentration (LIC).

In contrast, beta thalassemia major patients in whom cardiac iron overload is the major factor guiding therapeutic decisions, liver iron overload is a far greater concern in NTDT patients. Current data indicate that LIC and serum ferritin levels reach pathogenic levels in NTDT patients by $>10$ years 
of age. Elevated liver iron load is associated with hepatic fibrosis and increased risk of hepatocellular carcinoma; as well as other non-malignant complications like thrombosis, pulmonary hypertension, cerebrovascular accidents, hypothyroidism, hypogonadism, osteoporosis and renal dysfunction.[9] Ideally, LIC should be estimated by histopathology, but it is not feasible in majority of situations. In such cases, alternative methods like MRI and serial measurement of serum ferritin levels every 3 months may be used. Serum ferritin levels (SF) $>800 \mathrm{ng} / \mathrm{mL}$ found to be associated with increased mortality.

Nowadays safe and efficacious iron chelators are easily available, and the institution of chelation therapy at the appropriate time can minimize morbidity, thus improving the quality of life of the NTDT patients.[10]

The other parameters, i.e. presence of symptomatic anaemia, haemoglobin levels, facial dysmorphism, hepatomegaly, splenomegaly, BMI, height (in those $<18$ yrs. of age), serum glucose, calcium, phosphate, thyroid function, $\mathrm{FSH}, \mathrm{LH}$, testosterone (in males), endometrial thickness and presence of gallstones or leg ulcers were not found to be significantly related to serum ferritin levels.

The population of beta intermedia patients was too small to find out the differences in the rates of prevalence of complications in between the two groups.

\section{CONCLUSIONS}

Among the various parameters studied, 4 were found to be significantly related to the serum ferritin levels- delayed puberty, liver dysfunction, renal dysfunction and pulmonary hypertension. Thus, we conclude, that despite requiring much fewer transfusions than transfusion dependent thalassemia patients, the NTDT patients do develop iron overload as well as different complications, some of which are significantly related to the liver iron overload. Knowledge of such complications could help us initiate chelation therapy at the appropriate time for NTDT patients, thereby reducing morbidity and improving their quality of life.

\section{REFERENCES}

[1] Musallam KM, Rivella S, Vichinsky E, et al. Nontransfusion-dependent thalassemias. Haematologica 2013;98(6):833-44.

[2] Weatherall DJ. The definition and epidemiology of nontransfusion-dependent thalassemia. Blood Rev 2012;(26 Suppl 1):S3-6.

[3] Colah RB. Control Strategies for Hemoglobinopathies in India. Scientist F- Dept Director (SG), F Deputy (SG), National Institute of Immunohaematology, Parel, Mumbai.

[4] Musallam KM, Rivella S, Vichinsky E, et al. Nontransfusion-dependent thalassemias. Haematologica 2013;98(6):833-44.

[5] Gardenghi S, Grady RW, Rivella S. Anemia, ineffective erythropoiesis and hepcidin: interacting factors in abnormal iron metabolism leading to iron overload in beta-thalassemia. Hematol Oncol Clin North Am 2010;24(6):1089-107.

[6] Musallam KM, Cappellini MD, Wood JC, et al. Elevated liver iron concentration is a marker of increased morbidity in patients with $\beta$ thalassemia intermedia. Haematologica 2011;96(11):1605-12.

[7] Eldor A, Rachmilewitz EA. The hypercoagulable state in thalassemia. Blood 2002;99(1):36-43.

[8] Musallam KM, Cappellini MD, Daar S, et al. Serum ferritin levels and morbidity in $\beta$-thalassemia intermedia: a 10 year cohort study. Blood 2012;120(21):1021.

[9] Olivieri NF, De Silva S, Premawardena A, et al. Iron overload and iron-chelating therapy in hemoglobin Ebeta thalassemia. J Pediatr Hematol Oncol 2000;22(6):593-7.

[10] Taher AT, Porter J, Viprakasit V, et al. Deferasirox reduces iron overload significantly in non-transfusiondependent thalassemia: 1-year results from a prospective, randomized, double-blind, placebocontrolled study. Blood 2012;120(5):970-7. 